\title{
Method of preparing isolated colonic epithelial cells (colonocytes) for metabolic studies
}

\author{
W. E. W. ROEDIGER AND S. C. TRUELOVE \\ From the Nuffield Department of Surgery and Clinical Medicine, University of Oxford, Radcliffe \\ Infirmary, Oxford
}

SUMMARY Suspensions of isolated colonic epithelial cells (colonocytes) have been obtained from rats by incubating everted lengths of colon with EDTA at $37^{\circ} \mathrm{C}$ in Krebs-Henseleit saline from which calcium was omitted and containing $0 \cdot 25 \%(\mathrm{w} / \mathrm{v})$ bovine serum albumin. Measurements of oxygen consumption and lactate production by cell suspensions indicate that they are metabolically active for at least one hour. The method has been modified for the preparation of isolated epithelial cells from the human colon by including an enzyme digestion step and by increasing the concentration of EDTA to $10 \mathrm{mM}$. Human colonocytes have been obtained either from normal mucosa (ascending and descending coion) or from the mucosa in ulcerative colitis (descending colon). Oxygen consumption of human cell suspensions is lower than in the rat but in colonocytes from both species the rate is increased by glucose and by n-butyrate, a normal constituent of the colonic lumen. The method yields metabolically active cell suspensions from diseased colonic mucosa and promises to be of value for biochemical studies of ulcerative colitis.

There is hardly any information available on the metabolism of the epithelial cells of the human colonic mucosa. A study of the metabolism of these cells may help to elucidate colonic diseases such as ulcerative colitis and pseudomembranous colitis which affect the surface epithelial cells. We have therefore devised a method of isolating viable epithelial cells from normal and diseased mucosa of the human colon as well as from the rat colon for purposes of metabolic studies. These isolated cells are termed 'colonocytes' in order to distinguish them from enterocytes, a term generally used to describe absorptive cells of the small bowel (Johnson, 1976). The present usage of 'colonocytes' refers to all cells, columnar, goblet, crypt, and endocrine cells constituting the colonic epithelium.

The procedures are based, with modification, on the methods of Kimmich (1970), Culling et al. (1973), Hülsmann et al. (1974), and Watford (1977) for the preparation of isolated cell suspensions from the small intestine of various laboratory animals. In principle mucosal cells are exposed to the chelating agent EDTA which weakens the intercellular junctions to allow mechanical disaggregation of the surface epithelium. Several methods were tried before the following procedure was routinely

Received for publication 4 January 1979 adopted as it produced cells of optimal metabolic performance.

\section{Methods}

PREPARATION OF ISOLATED RAT

COLONOCYTES

Three male rats of the Cobb-Wistar strain (Charles River, Margate, Kent), 200-250 g were killed by a blow to the head and subsequent cervical fracture. The colons, from the caecum to the rectal ampulla, were rapidly removed and flushed clear with an electrolyte solution (Krebs and Henseleit, 1932) from which calcium was omitted, kept at $22^{\circ} \mathrm{C}$ and saturated with $\mathrm{O}_{2}+\mathrm{CO}_{2}(19: 1 \mathrm{v} / \mathrm{v})$. Each colon was everted, distally ligated, and then distended as much as possible by means of a syringe containing calciumfree Krebs-Henseleit (K-H) saline with $0.25 \%$ w/v dialysed bovine serum albumin (BSA). BSA was prepared and dialysed against calcium-free physiological saline as described by Krebs et al. (1974). The proximal end of the colon was ligated and the everted colon was placed in a plastic flask containing $100 \mathrm{ml}$ calcium-free $\mathrm{K}-\mathrm{H}$ saline, $5 \mathrm{mM}$ EDTA, and $0.25 \%$ BSA. The flask was continuously gassed with $\mathrm{O}_{2}+\mathrm{CO}_{2}(19: 1 \mathrm{v} / \mathrm{v})$ and incubated at $37^{\circ} \mathrm{C}$ in a Dubnoff type shaker at $60-70$ oscillations per minute for 30 minutes. Thereafter the colons were 484 
rinsed in fresh calcium-free saline to remove excess EDTA and placed in a plastic beaker with $50 \mathrm{ml}$ $\mathrm{K}-\mathrm{H}$ saline with $0.25 \% \mathrm{w} / \mathrm{v}$ BSA. Vigorous manual stirring with a plastic stirrer for two minutes readily disaggregated colonocytes, which were then separated by centrifugation at $500 \mathrm{~g}$ for 60 seconds. The cells were twice washed in oxygenated $\mathrm{K}-\mathrm{H}$ saline containing normal amounts of calcium, $5 \mathrm{mM}$ DL-dithiothreitol (DTT), and $2.5 \% \mathrm{w} / \mathrm{v}$ BSA. The pellet of cells was resuspended in $15 \mathrm{ml}$ of the same saline by being taken up several times into a $10 \mathrm{ml}$ polypropylene pipette. Aliquots of the cell suspension were used for the procedures outlined below.

\section{PREPARATION OF ISOLATED HUMAN COLONOCYTES}

The human material was obtained from surgical specimens of patients subjected to inhalation anaesthesia with halothane, nitrous oxide, and oxygen. The mesenteric vascular supply of a preselected section of a colectomy specimen was preserved at the time of operation until the vessels to this section remained as the only tether. The vascularly perfused portion of the colon was collected in the operating theatre, cut open, thoroughly washed with water $\left(37^{\circ} \mathrm{C}\right)$ and pinned out on a corkboard. Strips of mucosa were lifted with forceps and cut from the underlying muscle layers. The time taken from clamping off the blood supply to placing the mucosa in calcium free $\mathrm{K}-\mathrm{H}$ saline was less than six minutes. Mucosal tissue from $80-120 \mathrm{sq} \mathrm{cm}$ of colon was collected and placed in calcium-free $\mathrm{K}-\mathrm{H}$ saline with $5 \mathrm{mM}$ DTT, previously gassed with $\mathrm{O}_{2}+\mathrm{CO}_{2}$ $(19: 1 \mathrm{v} / \mathrm{v})$. Mucosal strips were then processed as shown in Fig. 1.
EFFICIENCY OF HARVESTING AND METABOLIC PERFORMANCE OF ISOLATED COLONOCYTES

\section{Efficiency of cell removal}

In order to assess the efficiency of colonic epithelial cell removal, pieces of mucosa were fixed in $10 \%$ formalin saline both before and after separation of the surface epithelium. The tissue was processed for paraffin embedding and sections stained with haematoxylin and eosin.

\section{Integrity of cell membranes}

The integrity of the cell menibrane of colonocytes was assessed by the ability of cells to exclude dyes and sodium succinate. The cell suspension $(0 \cdot 1 \mathrm{ml})$ was mixed with $0.2 \mathrm{ml}$ of $0.2 \%(\mathrm{w} / \mathrm{v})$ trypan blue in $150 \mathrm{mM} \mathrm{NaCl}$ or with $0.02 \mathrm{ml}$ of a succinatetetrazolium salt mixture (13 $\mathrm{mM}$ of 2-(4-indophenyl)3-(4-nitrophenyl)-5-phenyl tetrazolium chloride, $60 \mathrm{mM}$ sodium succinate, and $80 \mathrm{mM}$ sodium chloride). Cells were permeable to sodium succinate if a brown red formazan deposit occurred in the mitochondria or were permeable to trypan blue if nuclear staining occurred. Nuclear staining of trypan blue and appearance of a formazan deposit are of equivalent value in detecting damaged cell membranes of hepatocytes (Hems, unpublished observation, 1978). Both methods were used in the present study, as albumin in which isolated cells are suspended may inhibit staining by trypan blue. The proportion of permeable cells is expressed as a percentage of the total cell population counted in haemocytometer chambers.

Measurement of glycolysis

Production of lactic acid was used as a measure of

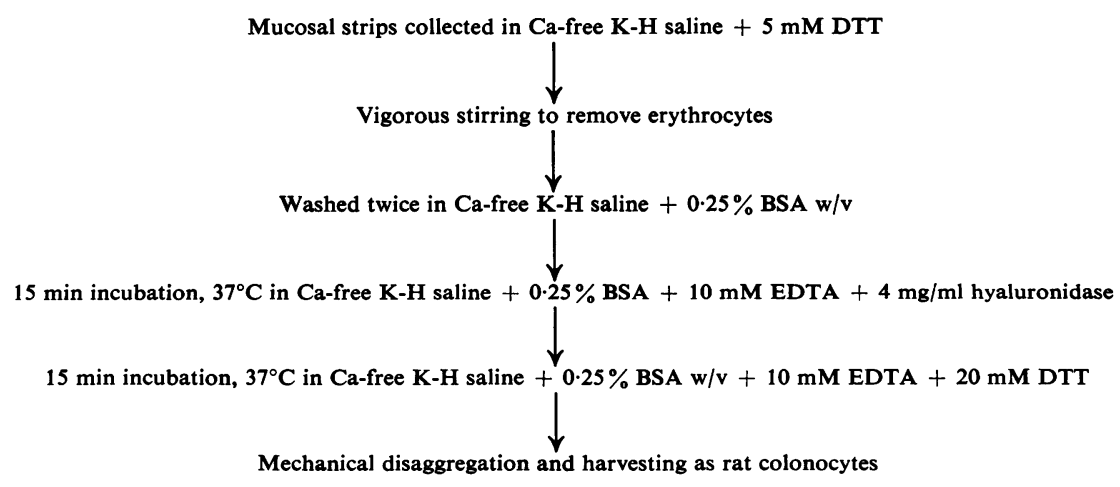

Fig. 1 Stages in the preparation of isolated human colonocytes. 
glycolysis. Cell suspensions, $1 \mathrm{ml}$, representing approximately $5 \mathrm{mg}$ dry weight of cells were incubated at $37^{\circ} \mathrm{C}$ in $1 \mathrm{ml} \mathrm{K}-\mathrm{H}$ saline containing $2.5 \%$ w/v BSA with or without $10 \mathrm{mM}$ glucose. The reaction was stopped at 20,40 , and 60 minutes by adding $0.5 \mathrm{ml}$ of $10 \%$ perchloric acid. The protein precipitate was separated by centrifugation and the supernatant neutralised with $20 \%$ potassium hydroxide. The lactic acid content was measured enzymatically by the method of Hohorst (1970) and the results expressed as $\mu \mathrm{mol} / \mathrm{g}$ (dry weight) of cells. The dry weight was obtained by drying $1 \mathrm{ml}$ of the cell suspension to constancy at $100^{\circ} \mathrm{C}$, and corrected for the dry weight of the albumin containing medium.

\section{Oxygen consumption of isolated colonocytes}

Oxygen uptake was measured manometrically in manometer cups designed by Krebs et al. (1974). Each cup contained $2 \mathrm{ml}$ of cell suspension, substrates (10 mM glucose and/or $10 \mathrm{mM}$-butyrate), and $\mathrm{K}-\mathrm{H}$ saline with $2.5 \% \mathrm{w} / \mathrm{v}$ BSA to a volume of $4 \mathrm{ml}$. The centre well contained $4 \mathrm{ml}$ of $\mathrm{CO}_{2}$-absorbing buffer (Krebs et al., 1974) and the gas phase was $\mathrm{O}_{2}+\mathrm{CO}_{2}(19: 1 \mathrm{v} / \mathrm{v})$. The manometer vessels were shaken at 60 oscillations per minute at $37^{\circ} \mathrm{C}$ with an amplitude of $2 \cdot 5-3.0 \mathrm{~cm}$. The oxygen consumption was expressed as $\mu \mathrm{mol} \mathrm{O} 2 / \mathrm{min} / \mathrm{g}$ tissue (dry weight).

\section{Bacteria and colonocyte suspensions}

In spite of thorough colonic lavage bacteria could have contributed towards lactate formation observed in cell suspensions. Lactate formation was therefore measured in rat cell suspensions containing $180 \mathrm{U} / \mathrm{ml}$ benzyl penicillin (Glaxo Laboratories) and $180 \mu \mathrm{g} / \mathrm{ml}$ streptomycin (Glaxo Laboratories) and compared with lactate formation by cell suspensions without these antibiotics.

Aliquots of colonocytes, with and without the above antibiotics, were plated on McConkey's medium, blood agar, and cooked meat broth to observe bacterial growth. In addition, the bacterial content was observed at the beginning and end of a one hour incubation of cell suspensions with 10 $\mathrm{mM}$ glucose as outlined above.

\section{Results}

With the present method more than $95 \%$ of the available surface epithelium of the rat colon was harvested as isolated cells. The efficiency of cell removal in rats was consistent and in every case the lamina propria, on histological section, seemed to be intact. Efficiency of epithelial cell removal in man was good and consistent in the ascending colon (Fig. 2) but varied in the rectosigmoid region where mainly surface but not crypt cells were removed. Very efficient harvesting of human colonocytes was observed from any site of the colon if patients had previously been treated with corticosteroids.

Cell suspensions, both in rat and man, contained a mixture of single colonocytes and clumps of cells conforming to the shape of colonic crypts. Mucus and occasional lymphocytes were also seen but no muscle or connective tissue structures.

There was no staining of colonocytes with trypan blue. This observation was probably an artefact as dye may bind to albumin contained in the cell suspension. A formazan deposit was seen in 15-30\% of rat and human colonocytes. This value was lower in cells prepared without mucolytic agents but such agents were nevertheless routinely used as they improved cell dispersion and oxygen consumption (Table 1).

The rate of oxygen consumption of rat colonocytes with or without substrates was linear over 60 minutes. The rate of consumption was increased by

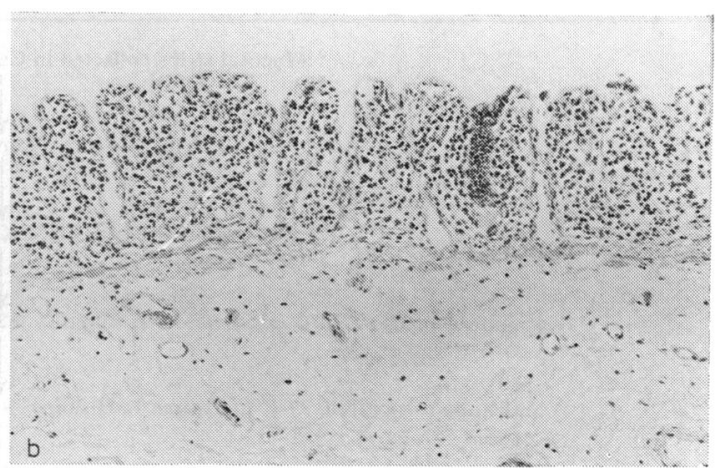

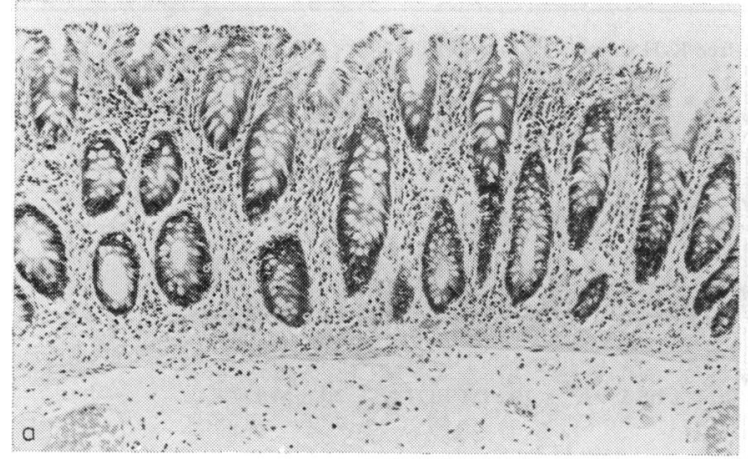

Fig. 2 Human colonic mucosa (a) intact mucosa and (b) after harvesting surface epithelial cells. Normal ascending colon. Sections $a$ and $b$ are not strictly comparable as they are taken from different areas of the same colectomy specimen. Haematoxylin and eosin, $\times 156$ (original magnification). 
Table 1 Oxygen consumption ( $\mu \mathrm{mol} / \mathrm{min} / \mathrm{g}$ (dry weight)) of isolated rat colonocytes incubated for 60 min with mucolytic agents

\begin{tabular}{|c|c|c|c|}
\hline & No mucolytics & $5 \mathrm{mMDTT}$ & $\begin{array}{l}5 \mathrm{mM} \\
\text { n-acetyl- } \\
\text { L-cysteine }\end{array}$ \\
\hline $\begin{array}{l}\text { No substrate } \\
10 \mathrm{mM} \text { glucose } \\
10 \mathrm{mM} \text { n-sodium } \\
\text { butyrate }\end{array}$ & $\begin{array}{l}7.29 \pm 0.12(3) \\
10.27 \pm 1.05(3) \\
10.81 \pm 0.99(3)\end{array}$ & $\begin{array}{l}12.96 \pm 1 \cdot 14(8) \\
15.30 \pm 0.98(10)^{*} \\
16.88 \pm 1 \cdot 18(4)^{*}\end{array}$ & $\begin{array}{c}\overline{-} \\
13 \cdot 39(2) \\
-\end{array}$ \\
\hline
\end{tabular}

Mean and SEM of the number of experiments in parentheses. Compared against endogenous oxygen consumption; paired $t$ test $(n=4) ;{ }^{*} P<0.001$.

glucose or n-butyrate and generally improved in the presence of mucolytic agents (Table 1). The rate of oxygen consumption of human colonocytes was also linear over 60 minutes but human cells under the conditions of preparation generally had a lower rate of consumption than rat colonocytes (Table 2).

The rate of lactate production from glucose was linear over 60 minutes and, as expected, was low in the absence of glucose (Fig. 3). Mean lactate production by cell suspensions with antibiotics was not significantly different from lactate production by cells without antibiotics.

Culture of suspensions of colonocytes revealed a scanty growth of enterobacteraceae which were eliminated by antibiotics. The concentration of microorganisms at the end of a one hour experiment was $1 \times 10^{-4}$ to $2 \times 10^{-4}$ bacteria per $2 \mathrm{ml}$ of colonocyte suspension and was decreased (less than $1 \times 10^{-4}$ per $2 \mathrm{ml}$ cell suspension) by antibiotics.

\section{Discussion}

Based on the criteria of cell permeability, oxygen consumption, and lactate formation, it seems that viable suspensions of colonocytes can be obtained from the lining epithelium of the rat colon. Such cell suspensions are free from muscle and connective tissue which may be present in mucosal scrapings of the colonic mucosa. Methods to prepare surface epithelial cells by scraping have been reported by Rosenthal and Lasnitzki (1928) and Perret et al.

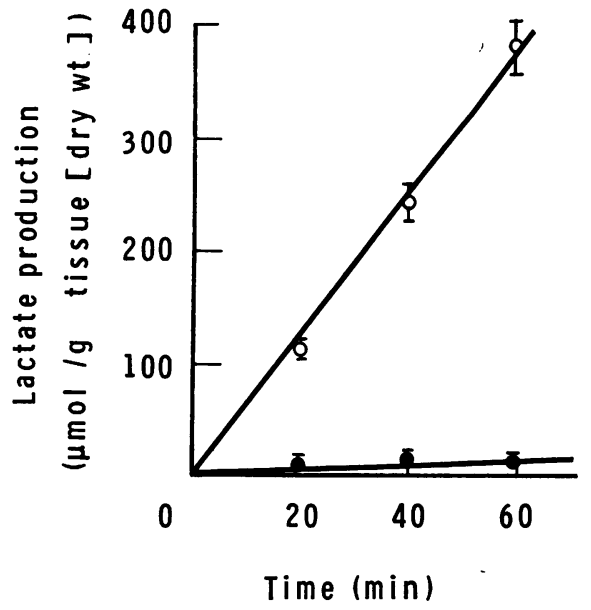

Fig. 3 Lactate formation by isolated rat colonocytes. Endogenous rate (O-O) or with $10 \mathrm{mM}$ glucose (O-O). Mean and $S E$ of five experiments (glucose) and three experiments (endogenous).

(1977) but have not been used extensively for metabolic studies.

The oxygen consumption is higher with isolated cell suspensions than with mucosal scrapings. Rosenthal and Lasnitzki (1928) report a consumption of $10.9 \mu \mathrm{mol} / \mathrm{min} / \mathrm{g}$ (dry weight) from scrapings of the rat colon incubated with glucose, while Perret et al. (1977) report virtually no oxygen consumption from the rat mucosa in the absence of any substrates. The high value presently obtained in the absence of substrates must reflect the utilisation of endogenous substrates which are not removed during cell preparation. An oxygen consumption of $8.41 \mu \mathrm{mol} / \mathrm{min} / \mathrm{g}$ (dry weight) is reported for scrapings of the human rectal mucosa (Rosenthal and Lasnitzki, 1928). This value is similar to that obtained with the present method for cells of the descending colon.

Oxygen consumption is enhanced in rat and man by glucose and $n$-sodium-butyrate, both of which are available to the colonic epithelium in vivo. Anae-

Table 2 Oxygen consumption of human colonocytes ( $\mu$ mol/min/g (dry weight)) incubated for 60 min with $10 \mathrm{mM}$ DTT and substrates as indicated

\begin{tabular}{|c|c|c|c|}
\hline & Ascending colon (normal) & Descending colon (normal) & $\begin{array}{l}\text { Descending colon (quiescent } \\
\text { colitis + corticosteroids) }\end{array}$ \\
\hline $\begin{array}{l}\text { No substrate } \\
10 \mathrm{mM} \text { glucose } \\
10 \mathrm{mM} \text { glucose }+10 \mathrm{mM} \text { sodium } \\
\mathrm{n} \text {-butyrate }\end{array}$ & $\begin{aligned} 8 \cdot 29 & \pm 0 \cdot 57(7) \\
9 \cdot 29 & \pm 0 \cdot 60(7) \dagger \\
10 \cdot 97 & \pm 0.64(7) \ddagger\end{aligned}$ & $\begin{array}{l}7 \cdot 47 \pm 0 \cdot 69(7) \\
7 \cdot 88 \pm 0 \cdot 83(7)^{*} \\
9 \cdot 31 \pm 0.58(7) \ddagger\end{array}$ & $\begin{array}{r}8 \cdot 43 \pm 0 \cdot 53(5) \\
9 \cdot 44 \pm 0 \cdot 48(5)^{*} \\
11 \cdot 13 \pm 0 \cdot 38(5) \S\end{array}$ \\
\hline $10 \mathrm{mM}$ n-butyrate & $10 \cdot 11 \pm 0.56(7) \dagger$ & $9 \cdot 30 \pm 0.83(7) \ddagger$ & 一 \\
\hline
\end{tabular}

Mean and SEM of the number of colectomy specimens in parentheses.

Compared against endogenous oxygen consumptions; paired $t$ test; ${ }^{*} \mathrm{NS}, \uparrow \mathrm{P}<0.025, \ddagger \mathrm{P}<0.005, \S \mathrm{P}<0.001$. 
robic bacteria in the colon produce n-butyrate, of which considerable amounts are absorbed (Dawson et al., 1964). The increase of oxygen consumption by n-butyrate suggests that this fatty acid is metabolised by the colonic epithelium, an observation which has been reported in the rabbit colon (Henning and Hird, 1972).

From a theoretical point of view the colonic epithelial cells in ulcerative colitis might be expected to tolerate the stress of cell isolation less well than the epithelial cells of normal mucosa. However, the present method produces colonocytes from colitic mucosa which have oxygen consumptions like that of normal cells. They thus seem metabolically active and could be useful for investigating ulcerative colitis.

In conclusion, isolated cell suspensions are a convenient way of studying mucosal epithelial cells in health and in disease. The oxygen consumption of cell suspensions is higher than that obtained with mucosal scrapings and cell suspensions have the further advantage that they are homogeneous and therefore permit parallel experiments to be carried out on the same tissue.

We are indebted to Dr Patricia Lund and Dr John Porteous, FRSE, for helpful discussions and encouragement during the course of this work.

\section{References}

Culling, C. F. A., Reid, P. E., Trueman, L S., and Dunn,
W. L. (1973). A simple method for the isolation of viable epithelial cells of the gastrointestinal (GI) tract. Proceedings of the Society for Experimental Biology and Medicine, 142, 434-438.

Dawson, A. M., Holdsworth, C. D., and Webb, J. (1964). Absorption of short chain fatty acids in man. Proceedings of the Society for Experimental Biology and Medicine, 117, 97-100.

Henning, S. J., and Hird, F. J. R. (1972). Ketogenesis from butyrate and acetate by the caecum and the colon of rabbits. Biochemical Journal, 130, 785-790.

Hohorst, H. H. (1970). L-(+)-lactat. Bestimmung mit Lactat-dehydrogenase und NAD. In Methoden der Enzymatischen Analyse, pp. 1425-1429. Edited by H. U. Bergmeyer. Springer: Berlin.

Hülsmann, W. C., van den Berg, J. W. O., and de Jonge, H. R. (1974). Isolation of intestinal mucosa cells. Methods in Enzymology, 32, 665-673.

Johnson, F. R. (1976). The absorptive cell. In The Cell in Medical Science, pp. 307-362. Edited by F. Beck and J. B. Lloyd. Academic Press: New York.

Kimmich, G. A. (1970). Preparation and properties of mucosal epithelial cells isolated from small intestine of the chicken. Biochemistry, 9, 3659-3668.

Krebs, H. A., Cornell, N. W., Lund, P., and Hems, R. (1974). Isolated liver cells as experimental material. In Regulation of Hepatic Metabolism, Edited by $\mathrm{F}$. Lundqvist and $\mathrm{N}$. Tygstrup. (Alfred Benzon Symposium VI), pp. 726-750. Munksgaard: Copenhagen.

Krebs, H. A., and Henseleit, K. (1932). Untersuchungen über die Harnstoff bildung im Tierkörper. Hoppe-Seyler's Zeitschrift für physiologische Chemie, 210, 33-66.

Perret, V., Lev, R., and Pigman, W. (1977). Simple method for the preparation of single cell suspensions from normal and tumorous rat colonic mucosa. Gut, 18, 382-385.

Rosenthal, O., and Lasnitzki, A. (1928). Uber den Stoffwechsel stationärer und wachsender Gewebe. Biochemische Zeitschrift, 196, 340-425.

Watford, M. (1977). The Regulation of Mammalian Glutamine Metabolism. Thesis: Oxford. 